<総 説 $>$

(受理 : 平成 28 年 8 月 29 日)

\title{
抗体を固定化する単分子膜表面の構築 \\ Fabrication of Monolayer Surface to Immobilize Atibody
}

\author{
田中睦 生* \\ Mutsuo TANAKA
}

\section{1.はじめに}

抗体とは, あるタンパク質と特異的に結合する免疫グロ ブリンの総称であり，この特異的結合性によって抗体は夕 ンパク質を取り扱うライフサイエンス研究に执いて必須の ツールとなっている。1975 年に抗体産生法が見いだされ て以来, 免疫学的測定・解析, 細胞や夕ンパク質の機能解 析, 遺伝子の発現スクリーニングなど，生命現象を個々の タンパク質レベルで解析する研究において様々な抗体が利 用されている。昨今では, 近未来の医療を担う薬としても 抗体は注目されている。このような抗体の特異的結合性を 用いた測定機器の一つとしてバイオセンサがある。診断・ 治療に有用なバイオマーカーやホルモンなどの生体関連物 質を測定するために，抗体の特異的結合性（抗原抗体反応） を利用した様々なバイオセンサが開発されている1,2)。抗 体を利用した生体関連物質検出には, 抗体のセンシング表 面への固定化法やタンパク質の非特異吸着抑制法など, 様々 な技術が必要である ${ }^{3,4)}$ 。本稿では，導波モードセンサ 5 7) をバイオセンサとして用いるために検討した，バイオセン シング界面構築法について紹介する。

\section{2. バイオセンシング界面の構築 ${ }^{8)}$}

抗体の固定化法には，物理吸着固定化法 ${ }^{9,10)}$ と化学結 合固定化法 ${ }^{11,12)}$ がある。物理吸着固定化法では，測定中 の抗体剥離や吸着による抗体の变性の問題があるため, 化 学結合固定化法が望ましいとされている。抗体をセンシン グ表面に化学結合固定化する手法として，アミノ基と反応 するスクシンイミドエステルや，メルカプト基と反応する マレイミドを有する表面修飾材料でセンシング表面を修飾

* 国立研究開発法人 産業技術総合研究所 健康工学部門 茨城県つくば市東 1-1-1 中央第 6 个 305-8566 Advanced Industrial Science and Technology (AIST) Health Research Institute

1-1-1 Higashi, Tsukuba, Ibaraki 305-8566, Japan
し，修飾表面と抗体を反応させて固定化するという手法が 開発され，様々なバイオセンサに用いられている。

バイオセンサの測定試料は血清や唾液が代表的であり, いずれの試料にあ様々なタンパク質が多量に含まれている。 タンパク質には物質表面に物理的，すなわち非特異的に吸 着する性質があり，センシング表面にも同様な現象が起こ る。このような非特異吸着がセンシング表面に起こると測 定感度は著しく低下するために，タンパク質の非特異吸着 抑制はバイオセンサ開発に打ける大きな課題となっている。 さらには, タンパク質の一種である抗体は, 非特異吸着 によって基板に吸着されると失活しまうことが知られてい る ${ }^{13)}$ 。非特異吸着を抑制するために様々な表面修飾材料が 開発されていて，ポリエチレングリコール (PEG) ${ }^{14 \sim 16)}$ は非特異吸着を抑制するための代表的な表面修飾材料とし て広範に用いられている。高分子ではないオリゴエチレン グリコール17 20) の場合でも，自己集合膜（SAM）のよう な単分子膜とすることによって非特異吸着を抑制できるこ とが報告され，様々な官能基が単分子膜状態において非特

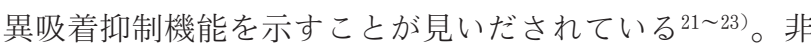
特異吸着抑制材料として最近注目されているのは，ホスホ リルコリン 24 27) やスルホベタイン 28,29) などのッビッター

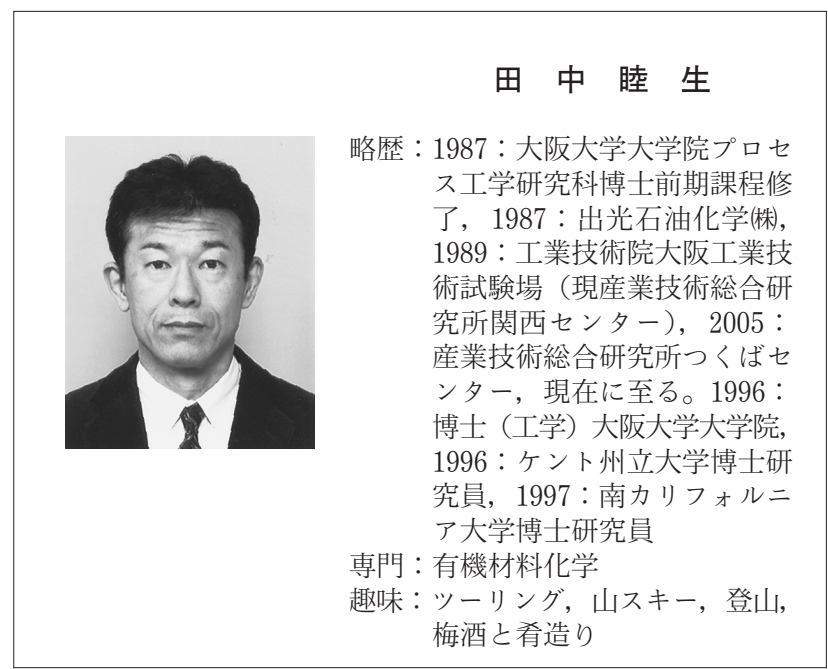




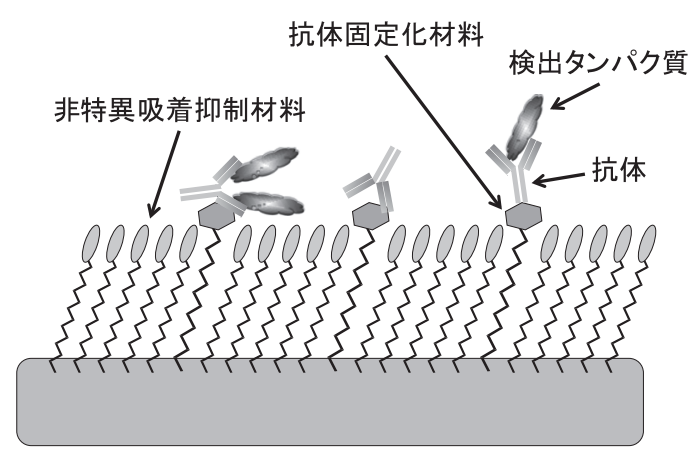

図 1 バイオセンシング界面模式図

イオン型官能基を導入した材料である。

以上の理由からバイオセンシング界面構築には, 抗体を 固定化でき，かつタンパク質等の非特異吸着を抑制できる 修飾表面が必要である。このような二重機能修飾表面を構 築する手法として, 抗体を固定化する表面修飾材料と非特 異吸着を抑制する表面修飾材料を用いた混合表面修飾法が ある。図 1 には, 抗体固定化機能と非特異吸着抑制機能と いう二重機能を有する修飾表面を用いて構築したバイオセ ンシング界面の模式図を示す。

導波モードセンサは, 表面プラズモン共鳴（SPR） セ ンサに類似したシステムを持つ, 近接場光を利用したセン サの一つである ${ }^{5 \sim 7)}$ 。導波モードセンサをバイオセンサと して利用するために, バイオセンシング界面の構築に用い る表面修飾材料を検討した。導波モードセンサのセンシン グ表面はガラスであるので, ガラス表面と反応し, かつ精 製が容易であるトリエトキシシランを導入した表面修飾材 料の分子設計を行った。抗体固定化と非特異吸着抑制を担 う官能基は, トリエトキシシラン部位と反応しないことが 必須であるので, メトキシオリゴエチレングリコールを非 特異吸着抑制官能基に，スクシンイミドエステルを抗体固 定化官能基に選定した。オリゴエチレングリコールの非特 異吸着抑制機能に関しては，鎖長が長い方が効果的である との報告があるので ${ }^{17,19)}$, 比較検討のためトリ (M3EG), テトラ (M4EG), ペンタエチレングリコール誘導体 (M5EG) を合成した（図 2)。

混合表面修飾では，二重機能を発揮させるためには表面 修飾材料の鎖長の組合せが重要であることが明らかになっ ている19)。そこで図 3 に示すように，それぞれの非特異吸 着抑制材料よりもわずかに鎖長が長い抗体固定化材料 3 種 類を合成した。

これらの表面修飾材料を用いて目的とする非特異吸着抑 制機能や抗体固定化機能を持つ表面を構築するには, 図 1 の模式図のように自己集合膜同等の表面濃度が高い単分子 膜を形成させる必要がある ${ }^{30)}$ 。そこで非特異吸着抑制材料 のトルエン溶液を調整し, 様々な条件下でセンシングチッ プの表面修飾を行い, 最適表面修飾条件を探索した。非特 異吸着抑制機能はウシ血清アルブミン（BSA）を用いて

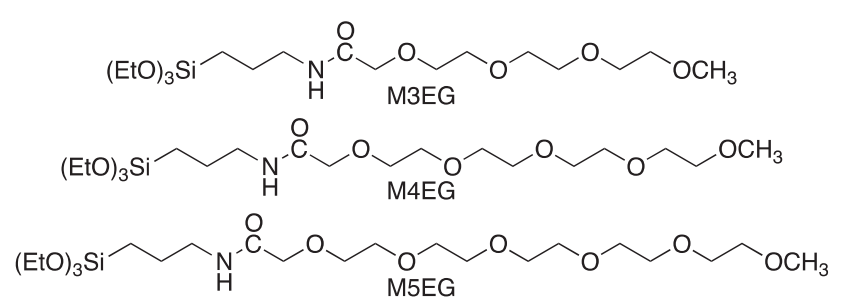

図 2 非特異吸着抑制表面修飾材料

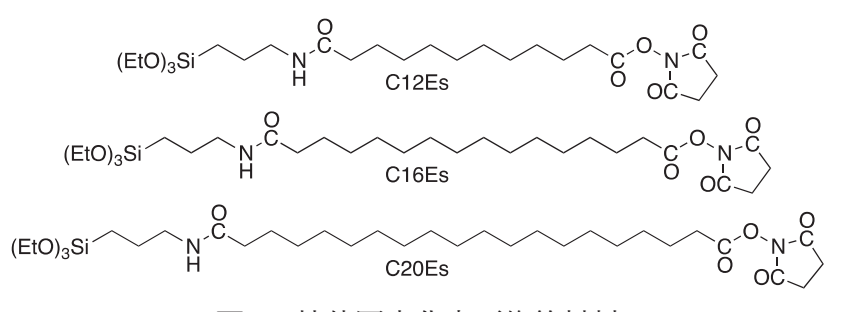

図 3 抗体固定化表面修飾材料

評価し, 表面修飾材料の表面濃度は X 線光電分光装置 （XPS）を用いて測定した。その結果，表面修飾材料の鎖 長が長くなるにつれて反応性が低下し, 非特異吸着抑制機 能が低下するという傾向が見られた。M3EG では室温 24 時間で十分な非特異吸着抑制効果が得られたが， M4EG では $50^{\circ} \mathrm{C} 24$ 時間, $\mathrm{M} 5 \mathrm{EG}$ では反応促進剂として $5 \mathrm{mM}$ の 酢酸を加えて $50^{\circ} \mathrm{C} 24$ 時間という条件が必要であった。次 にそれぞれの最適条件下で修飾した表面の非特異吸着抑制 効果を, ヒトコントロール血清を用いて評価した。血清に センシングチップを 5 分間浸漬し, 生理食塩水 (PBS) で 洗浄した場合（左側）と0.05\%界面活性剤（Tween20）入 り PBS で洗浄した場合（右側， $\mathrm{T}$ で表示）の非特異吸着 に起因する波長变化值を図 4 に示した。図には比較のため に未修飾チップの值む加えた。図 4 から明らかなように, オリゴェチレングリコールの鎖長が長い表面修飾材料が非 特異吸着抑制機能に優れ, 界面活性剂入りの PBS で洗浄 した場合は，いずれの表面修飾材料でも非特異吸着は検出 限界以下となることが明らかになった。

次に，非特異吸着抑制材料（M3EG）に抗体固定化材料 （C12Es）を混合して表面修飾を行い，その混合比による

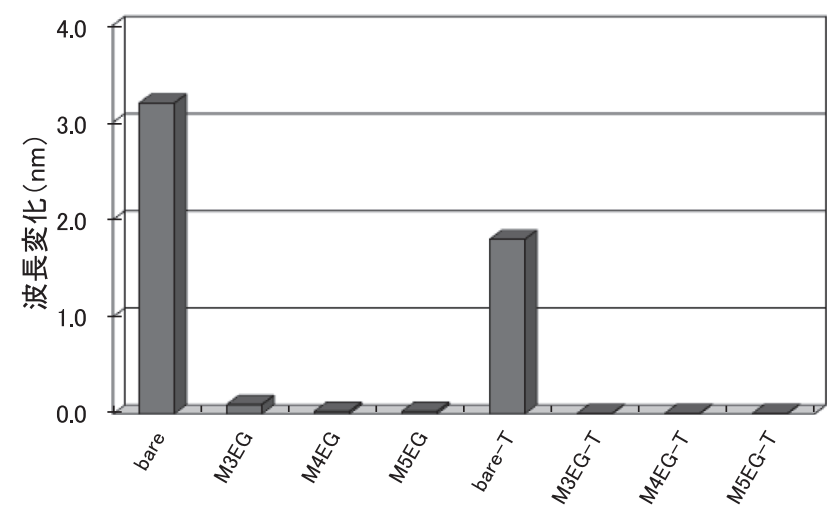

図 4 非特異吸着抑制材料の評価 


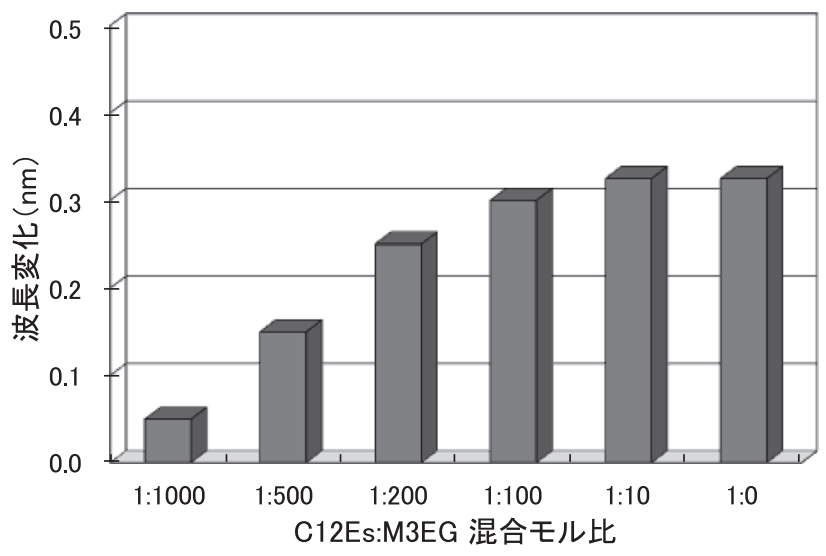

図 5 表面修飾材料混合比による応答変化

抗原抗体反応の变化を検討した。抗体には，糖尿病のプレ マーカーとして知られるレプチンに結合する抗レプチン抗 体を用いた。図 5 に示すように，抗体固定化表面修飾材料 のモル比が増加するにしたがって応答も増大するが，ある 程度以上は頭打ちとなる傾向が観測された。この傾向は, 抗体固定化材料のモル比増加にしたがって固定化される抗 体の表面濃度も増加するが，ある程度以上では“抗体の単 分子膜” 状となって飽和状態になることを反映しているた めと考えられる。

非特異吸着抑制材料と抗体固定化材料の組合せと混合比 を検討した結果を図 6 にまとめた。抗体固定化材料の鎖長 が長い場合，修飾表面への導入量が減少するために固定化 される抗体量も減少して応答が小さくなる傾向が見られた。
その一方で，C12Es 抗体固定化材料に，鎖長がより長い M4EG 非特異吸着抑制材料を混合した場合は，まったく 応答が見られなくなるという結果が得られた。このことは, 抗体固定化材料の鎖長は非特異吸着抑制材料の鎖長よりも 長くなければ抗体を固定化できないことを表している。

抗体固定化材料に C $12 \mathrm{Es}$ ，非特異吸着抑制材料に M3EG を用いてセンシング界面を構築し（混合モル比 $=1: 10$ ), PBS 中のレプチンの検出を実施した。図 7 に示すように, 数十 $\mathrm{ng} / \mathrm{mL}$ のレプチンが検出できることを見いだした。

次に，同じセンシング界面を用いてヒトコントロール血 清中のレプチン検出を行った。図 8 に示すように, PBS 中に比べて血清成分の非特異吸着によって若干感度は低下 するものの，100ng／mL のレプチンを検出できることか ら，抗体固定化材料之非特異吸着抑制材料からなる混合修 飾表面は，効果的に非特異吸着を抑制できることが明らか になった。

センシング基板に固定化した抗体は，基板への非特異吸 着によって失活してしまうため長期保存が困難であること が知られている13)。そこで $\mathrm{M} 3 \mathrm{EG}-\mathrm{C} 12 \mathrm{Es}$ を用いて抗体を 固定化したセンシングチップを冷蔵保管し，その応答性の 経時变化を検討した。その結果, 防腐剂としてアジ化ナト リウムを添加した PBS 中で保管したチップは，4 週間後 あまったく応答性に変化がないことを確認した。よって M3EG-C12Es 修飾表面は，抗体を固定化しつつ非特異吸 着を抑制するという優れた二重機能を有していることが示
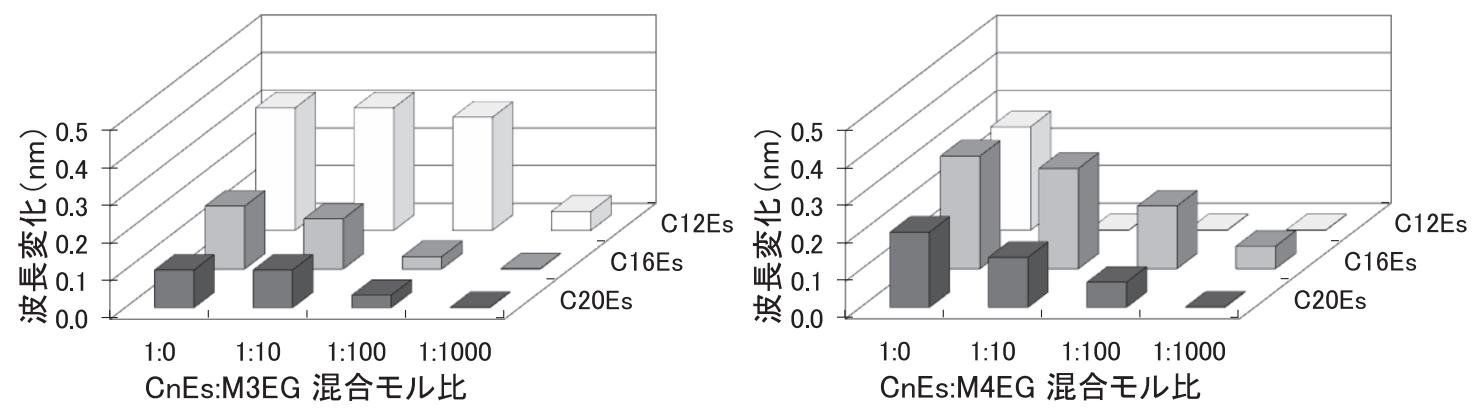

図 6 非特異吸着抑制材料一抗体固定化材料の組合せ之混合比

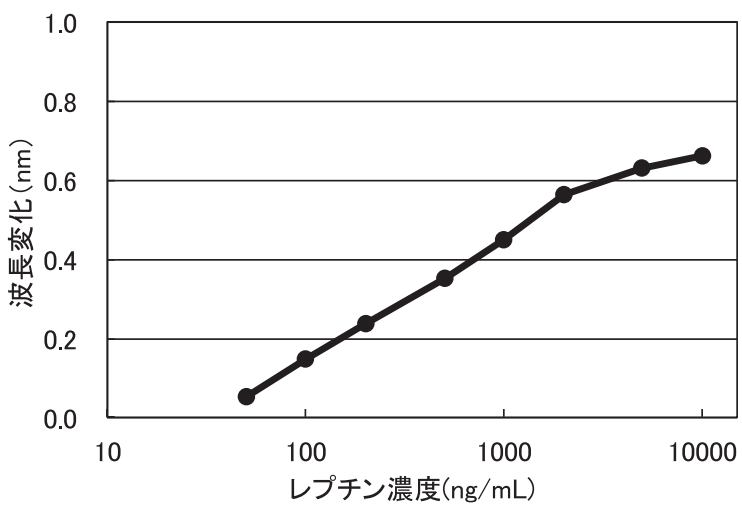

図 7 PBS 中のレプチンの検出

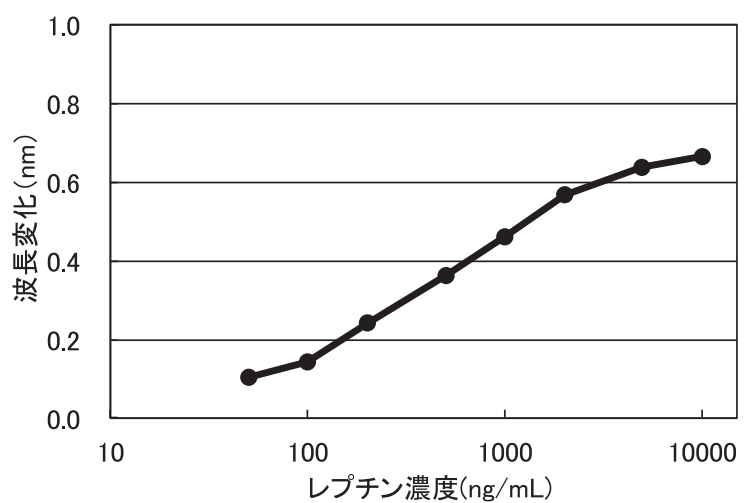

図 8 血清中のレプチン検出 
された。

同様に，様々な組合せの抗体固定化材料と非特異吸着抑 制材料を用いて表面修飾を行ってセンシング界面を構築し, 血清中のレプチン検出を実施した。非特異吸着抑制材料の みの修飾表面では，エチレングリコール鎖が長い表面修飾 材料が非特異吸着を効果的に抑制したが，抗体固定化材料 との混合修飾表面では, 鎖長が長い場合は血清の非特異吸 着によって著しく検出感度が低下するという現象が見られ た。そこで抗体固定化材料のみで表面修飾を行い, 非特異 吸着を比較したところ, 鎖長が長い抗体固定化材料は血清 の非特異吸着を誘起することが示された。非特異吸着に対 する抗体固定化材料と非特異吸着抑制材料の相反する鎖長 依存性の結果として, 鎖長が短い材料の組合せである, M3EG と C12Es を用いて構築したセンシング界面がもっ とも高感度にレプチンを検出できることが明らかになった。

より高感度に目的物を検出するために様々な増感法が考 案されている。中でも二次抗体を用いる増感法は最も効果 的な手法として知られている。二次抗体に酵素や䖢光色素 などを導入して増感を図る手法が開発されているが, ここ では単に二次抗体が検出タンパク質に結合することによる 増感を試みた。図 7 と同じ条件で測定した結果を図 9 に示 す。二次抗体を用いることにより数 $\mathrm{ng} / \mathrm{mL}$ のレプチン が検出できるようになり, 約 10 倍の感度増強が可能であ ることが見いだされた ${ }^{31)} 。$

一方で，抗体を用いたセンシング界面では，図 1 中に示 したように検出するタンパク質と結合する Fab 領域が基 板側に向いて固定化されることによる感度低下が指摘され ている。この課題を解決するために, 抗体の Fc 領域と結 合するプロティン $\mathrm{A}$ や $\mathrm{G}$ を用いて抗体の配向性をそろえ る増感法が試みられている ${ }^{32)}$ 。そこで本混合修飾表面にプ ロテイン $\mathrm{A}$ および $\mathrm{G}$ を固定化し，抗レプチン抗体を導入 したセンシング界面を構築して増感効果を検討したが, 有 意な増感効果は見られなかった。この結果は, プロティン A や $\mathrm{G}$ の配向性にも考慮する必要があることを示唆して いる。抗体の配向性制御には, 遺伝子操作によって抗体の

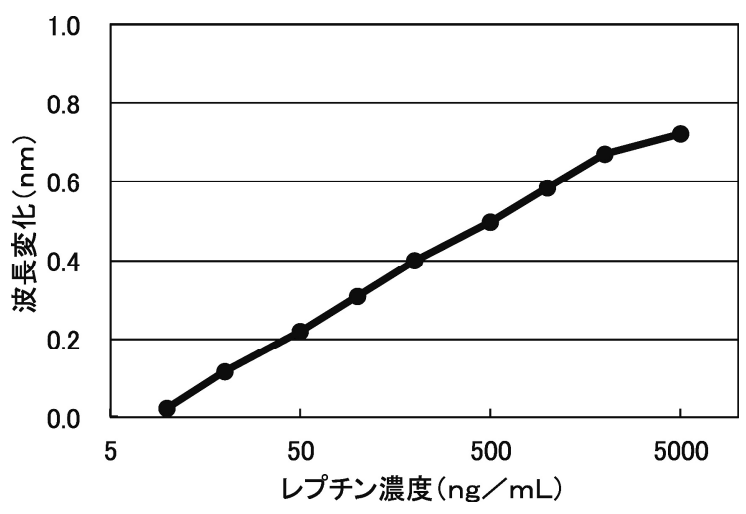

図 9
Fc 領域に基板と結合するアミノ酸配列を発現させるとい う生物学的手法が有効であることが報告されている13,33)

\section{3. まとめ}

抗体を固定化する表面修飾材料と非特異吸着を抑制する 表面修飾材料からなる混合表面修飾を, 分子レベルで制御 してセンシング素子に施すことによって，効果的に非特異 吸着を抑制しつつ目的タンパク質を検出できるセンシング 界面が構築できることを明らかにした。混合表面修飾にお ける要点は, 表面修飾材料分子の表面濃度を高める反応条 件で表面修飾を行うこと，材料分子の組合せで鎖長および 機能物性を考慮することであった。このような分子レベル での機能と構造を考慮した表面修飾法が，接着技術の展開 にも役立つことを期待している。

\section{文献}

1) H. Zhu, M. Snyder, Curr. Opin. Chem. Biol., 7, 55 (2003).

2) U. Hanefeld, L. Gardossi, E. Magner, Chem. Soc. Rev., 38, 453 (2009).

3) S. L. Seurynck-Servoss, A. M. White, C. L. Baird, K. D. Rodland, R. C. Zangar, Anal. Biochem., 371, 105 (2007).

4) Y. Kurihara, M. Takama, T. Sekiya, Y. Yoshihara, T. Ooya, T. Takeuchi, Langmuir, 28, 13609 (2012).

5) X. Wang, M. Fujimaki, T. Kato, K. Nomura, K. Awazu, Y. Ohki, Opt. Express, 19, 20205 (2011).

6) M. Fujimaki, C. Rockstuhl, X. Wang, K. Awazu, J. Tominaga, Y. Koganezawa, Y. Ohki, T. Komatsubara, Opt. Express, 16, 6408 (2008).

7) M. Fujimaki, K. Nomura, K. Sato, T. Kato, S. C. B. Gopinath, X. Wang, K. Awazu, Y. Ohki, Opt. Express, 18, 15732 (2010).

8) M. Tanaka, K. Yoshioka, Y. Hirata, M. Fujimaki, M. Kuwahara, O. Niwa, Langmuir, 29, 13111 (2013).

9) Z. Yang, Y. Chevolot, T. Géhin, J. Solassol, A. Mange, E. Souteyrand, E. Laurenceau, Biosens. Bioelectron., 40, 385 (2013).

10) Z. Yang, Y. Chevolot, T. Géhin, V. Dugas, N. Xanthopoulos, V. Laporte, T. Delair, Y. Ataman-Önal, G. ChoquetKastylevsky, E. Souteyrand, E. Laurenceau, Langmuir, 29, 1498 (2013).

11) F. Rusmini, Z. Zhong, J. Feijen, Biomacromolecules, 8, 1775 (2007).

12) P. Jonkheijm, D. Weinrich, H. Schröder, C. M. Niemeyer, H. Waldmann, Angew. Chem. Int. Ed., 47, 9618 (2008).

13) K. Yoshimoto, M. Nishio, H. Sugasawa, Y. Nagasaki, J. Am. Chem. Soc., 132, 7982 (2010).

14) X. Yuan, K. Yoshimoto, Y. Nagasaki, Anal. Chem., 81, 1549 (2009).

15) H. Lee, K. D. Lee, K. B. Pyo, S. Y. Park, H. Lee, Langmuir, 26, 3790 (2010).

16) W. Norde, D. Gage, Langmuir, 20, 4162 (2004).

17) S. Herrwerth, W. Eck, S. Reinhardt, M. Grunze, J. Am. Chem. Soc., 125, 9359 (2003).

18) C. E. Soteropulos, K. M. Zurick, M. T. Bernards, H. K. Hunt, Langmuir, 28, 15743 (2012).

19) Y. Sato, K. Yoshioka, M. Tanaka, T. Murakami, M. N. Ishida, O. Niwa, Chem. Commun., 4909 (2008).

20) K. Yoshioka, Y. Sato, T. Murakami, M. Tanaka, O. Niwa, 
Anal. Chem., 82, 1175 (2010).

21) R. G. Chapman, E. Ostuni, S. Takayama, R. E. Holmlin, L. Yan, G. M. Whitesides, J. Am. Chem. Soc., 122, 8303 (2000).

22) E. Ostuni, R. G. Chapman, R. E. Holmlin, S. Takayama, G. M. Whitesides, Langmuir, 17, 5605 (2001).

23) R. E. Holmlin, X. Chen, R. G. Chapman, S. Takayama, G. M. Whitesides, Langmuir, 17, 2841 (2001).

24) V. A. Tegoulia, W. Rao, A. T. Kalambur, J. F. Rabolt, S. L. Cooper, Langmuir, 17, 4396 (2001).

25) S. Chen, J.Zheng, L. Li, S. Jiang, J. Am. Chem. Soc., 127, 14473 (2005).

26) Y. Iwasaki, K. Ishihara, Anal. Bioanal. Chem., 381, 534 (2005).
27) M. Tanaka, T. Sawaguchi, Y. Sato, K. Yoshioka, O. Niwa, Tetrahedron Lett., 50, 4092 (2009).

28) A. T. Nguyen, J. Baggerman, J. M. J. Paulusse, C. J. M. van Rijn, H. Zuilhof, Langmuir, 27, 2587 (2011).

29) H. Jiang, X. B. Wang, C. Y. Li, J. S. Li, F. J. Xu, C. Mao, W. T. Yang, J. Shen, Langmuir, 27, 11575 (2011).

30) M. Tanaka, T. Sawaguchi, M. Kuwahara, O. Niwa, Langmuir, 29, 6361 (2013).

31）未発表デー夕

32） N. Tajima, M. Takai, K. Ishihara, Anal. Chem., 83, 1969 (2011).

33) Y. Kumada, Y. Ohigashi, Y. Emori, K. Imamura, Y. Omura, M. Kishimoto, J. Immunol. Meth., 385, 15 (2012). 